\title{
MONOGRAPH OF THE GENUS GNATHODON, GRAY (RANGIA, DESMOULINS).
}

[With plate VII.]

\author{
By WM. H. DALL, \\ Honorary Curator of the Department of Mollusks.
}

THE genus Gnathodon is one of those in regard to which much interest attaches, on account of its disputed place in the systems, its uncertain nomenclature, and its zoological peculiarities. In working up the Tertiary species it became necessary to review the whole group and investigate its relations afresh with newly collected material. Out of these researches, among other results, has grown the present monograph, which is believed to settle the systematic position and nomenclature of the genus.

\section{Genus GNATHODON, Gray.}

Gnathodon (Gray MS.), Sowerby, Gen. Sh. No. 36, Dec. 1831 (Type G. cuneatus Gray).-GraY, P. Z. S. 1836, p. 104.-Gray, Loudon's Mag. Nat. Hist. I, n. s., p. 376, 1838.-Conrad, Medial Tert. No. 1, p. 23, 1838.-An ron, Verz. Conch., p. 10, 1839.-Sby, Man. Conch., fig. 83, 1839.-Conrad, Medial Tert., No. 2, p. 69, 1840.-Swainson, Malac., p. 370, 1840.-Conrad, Am. Journ. Sei., XxxviII, p. 92, 1840.-ReEve, Conch. Syst. I, p. 62, pl. 43, 1841.-Conrad, 2 d Bull. Nat. Inst., pp. 190, 192, 1842.-DекаY, Moll. N. York, p. 233, 1843.-HANLEY, Descr. Cat. Rec. Sh., p. 35, pl. 10, fig. 22, 1843.-Potiez \& Mich., Gal. de Douai, II, p. 194, 1844.-GraY, Gen. Moll. P. Z. S., 1847, p. 186.-PhilipPI, Handbuch Conch., p. 317, 1853.-Woodward, Man., ed. I, p. 308, 1856.-DaLL, Bull. 37, U. S. Nat. Mus., p. 62, 1889.

Rangia, Desmoulins, Actes Soc. Lin. de Bordeanx, v, No. 25, p. 50, Feb. 15, 1832 (Type R. cyrenoides Desm.).-Conrad, Am. Mar. Conch., p. 56, 1833.H. \& A. Adams, Gen. Rec. Moll. II, p. 380, 1856.-Conrad, Proc. Acad. Nat. Sci., Phila., 1860, p. 232, 1861.-Conrad, Medial Tert. Index, p. 88, 1861.Prime, Proc. Bost. Soc. Nat. Hist. viI, p. 347, 1861.-Conrad, Am. Journ. Conch. III, suppl., p. 30, 1868.-Fischer, Man. de Conchyl., p. 1095, 1887.

Gnatodon, Rang, Nouv. Ann. du Mnséum, III, p. 217, 1834.

Columbia (Bllainville MS.), RaNG, op. cit., p. 217, 1834. 
Clathradon (Gray MS.), Conrad, Am. Journ. Sci., xxin, p. 340, Jan., 1833. Lapsus for Clathrodon, Gray MS., 1830.

Clathodon, Sowerby, Man., 2d ed., p. 108, 1842.

Perissodon, Conrad, Proc. Acad. Nat. Sci., Phila., 1862, p. 573, 1863 (Type P. Grayi, ConRAD = Mactra clathrodonta, CoNRAD, 1833).

Rangianella, Conrad, Am. Journ. Conch. III, suppl., p. 30, 1867 (Тype G. trigonum, Petit, Mazatlan, Mexico).

Shell trigonal, equivalve, closing completely; umbones prominent, not adjacent, smooth at the point of origin, erect or twisted forward; lunule and escutcheon obscure or absent; shell-substance porcelain-white internally; externally chalky, with a thin epidermis; anterior shorter than the posterior end; the latter produced or rostrate; hinge comprising a bifid triangular cardinal tooth in one valve over which fit two lamellar divergent teeth of the opposite valve, an accessory lamella sometimes rising from the anterior edge of the cartilage pit next the cardinals; an anterior lateral tooth in one valve received between two less prominent laminæ of the opposite valve, of which pair the dorsal lamina approaches nearer the cardinal tooth than the ventral one, leaving a gap into which the proximal end of the anterior lateral, when adult, is more or less distinctly hooked; a longer posterior lateral in the same valve as the anterior tooth, received between two subequal less prominent laminæ in the opposite valve; teeth crenulated or granulose on their opposed surfaces; cartilage pit deep, persistent; internal border of the valves smooth or faintly radiately striated; adductor scars distinct, the anterior smaller; pallial line distinct, distant from the margin; pallial sinus small, rather irregular; cartilage large, inserted on the ventral surface of the pit, persistent in its entirety, so that its distal ends sometimes project from the eroded umbones; ligament wholly internal, small, inserted on the dorso-posterior surface of the pit and separated by a shelly ridge on each side from the cartilage below it; mantle-edge smooth, simple, the lobes marginated, the inner edge of the margin thicker and elevated, the lobes free edged from below the anterior adductor nearly to the siphons; antesiphonal channel of the incurrent siphon longitudinally divided by an elevated raphe arising from the inner surface of the mantle; siphons moderate, united to their tips, their distal orifices sparsely papillose; the proximal orifice of the incurrent siphon with an imperfect arched valve; gills two on each side, the inner larger, suspended by its base; the outer smaller, its line of attachment crossing the gill obliquely and forming of the upper portion an "appendix" which is soldered to the mantle by most of its dorsal surface; all four gills united behind the foot, their proximal portion forming a septum which is anchored to the anterior portion of the siphonal septum, thus completely separating the anal and peripedal chambers; palpi, four in number, narrow, long, internally striated, externally smooth, the lower pair continuous medially in front of the foot; foot small, compressed, short, angular in front, pointed behind, ventral edge sharp, entire; byssus and byssal gland atrophied or absent in the adult. 
Distribution.-Subtropical America, the Gulfs of California and Mexico in shoal quiet water varying from salt to fresh, but preferably somewhat brackish, as in the case of oysters; range in time from the newer miocene to recent seas.

The genus falls naturally into three sections, the typical group best illustrated by G. cuneatus; a second, Miorangia, Dall, represented by the miocene G.Johnsoni, a very small, extremely inequilateral type with obsolete pallial sinus and the cardinals reversed, the superior pair being in the left valve; the other, named Rangianella by Conrad, being characterized by subequal faintly rugose lateral teeth, an obsolete pallial sinus, and a more equilateral elongate and smaller shell.

The subgenus Rangianella forms the transition toward Mulinia, and some of its species ean only be distinguished from species of Mulinia by the smaller pallial sinus and the inconspicuous "hook" on the proximal end of the anterior lateral tooth. A number of small species of Mulinia have been described under the name of Rangia or Gnathodon, so elose is the relation between them. Several species of Mulinia, if not all of them, are denizens of brackish water, and to errors based on these facts are due the statements which have represented Gnathodon as being extra-American in distribution.

As far as I have been able to judge from the specimens I have seen, the species described will be assorted as follows:

A: Gnathodon; typical group; G. cuneatus Gray, G. clathrodon Conrad, G. Grayi Conrad, G. Lecontei Conrad, G. minor Conrad.

B: Miorangia; G. Johnsoni Dall.

C: Rangianella; G. Alexuosus Conrad, G. rostratus Petit, G. trigonus Petit, G. mendicus Gould.

The other species hitherto described may be referred to Mulinia, Isocardia, and other groups external to the genus as properly restricted.

This genus has had singular nomenclatorial vicissitudes. The type species was well known to the early conchologists of the United States, and was regarded by them as identical with the problematical fossil named by Lamarck Cyrena truncata. Gray, from a ballast heap left in Canada by a vessel from the Gulf of Mexico, received two valves, which he described under the name of Clathrodon, and sent the manuscript to the editors of the American Journal of Science, to be published in America, about 1830. Believing it to be the same as Lamarck's species, the editors suppressed Gray's description. Later Gray substituted Gnathodon for the ill-constructed name Clathrodon, and the former was published by Sowerby in his "Genera of Mollusca," Part xxxvi. This was the first publication of the name Gnathodon, and appears to have been made in the last quarter of the year 1831,* the number containing

* See Newton, Brit. Oligocene and Eocene Moll., p. 321, 1891. Since writing this note the researches of Mr. C. Davies Sherborne, kindly undertaken at my suggestion, show that No. xxxvi was received and entered on the donation book of the Linnean Society, London, January 4, 1832; from which it may be inferred that the number in question was printed in the last days of December, 1831. 
it having references in it to the number of the Zoological Journal published September, 1831. In December, 1831, Desmoulins read to the Linnean Society of Bordeaux a paper published by that Society February 15, 1832, containing an excellent figure and account of the species under the name of Rangia cyrenoides, which name was adopted by Conrad in his American Marine Conchology, who at the same time mentioned the earlier unpublished Clathrodon of Gray. The "Genera" of Sowerby and Conrad's Marine Conchology were both rather obscure publications, the dates of several parts of which are difficult to discover, and both the authors, Gray and Conrad, appear to have forgotten about these early publications. The former in 1847 gives the date of his Gnathodon as "1837," which is possibly a misprint for 1831, Conrad in 1832 adopted Rangia; in 1833 he was disposed to revive Gray's manuscript name of Clathrodon on the ground of courtesy; in 1834 Rang seems to have no doubt that the name Gnathodon had been published before Desmoulins's Rangia, and adopts the former. In 1838 Conrad adopts Gnathodon, and uses it again in 1840. In 1860 he reverts to Rangia, and continues to use it in 1863 , when he proposes a subgeneric name, Perissodon, for the fossil $R$. Grayi, and in 1868 another subgeneric name, Rangianella, for a Pacific species. The latter of these names was defined. It may be noted that Gnathodon was employed by Jardine for a genus of birds in 1845, and Rangia by Agassiz, in 1860, for a genus of Colenterates. The name Gnathodon is masculine, and the specific names should take a masculine termination. Monographic lists of the genus have been printed by Conrad (Proc. Acad. Nat. Sci. Phila. for 1860, p. 232); Prime (Proc. Boston Soc. N. Hist., VII, p. 347, 1861); Fischer (Journ. de Conch., Ix, p. 212, 1861); Conrad (Am. Journ. Conch., III, Suppl. Cat. of Mactrida, p. 30, 1868); and Reeve (Conch. Icon., XIx, 1873). Singularly enough, neither of these authors has given the synonymy of the generic name correctly. The date of 1831, when Desmoulins's paper was read, is assigned to Rangia, which, however, was not published until February, 1832. The date of 1831 is assigned to Conrad's mention of the genus in his American Marine Conchology, though he adopts Rangia, which was not published until 1832, and it is highly probable that the part of Conrad's work containing Rangia did not appear until 1833, since it was contained in the fifth fasciculus, and the third fasciculus is dated May, 1832. At all events it can not be earlier than the latter part of 1832. Gray's manuscript name of Clathrodon was never formally proposed in print, and Conrad's earliest mention of it is in 1833.

Gray and Desmoulins both referred the genus to the Mactrida, while pointing out that in certain features it recalled Cyrenida. This view has generally prevailed, though lately Dr. Paul Fischer concluded (Manual, p. 1095) that it is more nearly related to Cyrena. Rang's notes on the anatomy were probably made on defective material; at all events, they contain several errors which tend to obscure the mactroid affini- 
ties of the shell. Dr. Fischer also raised the group to family rank, which, if it be compared solely with Cyrenida, is reasonable, but, if the comparison is with the Mactrida, and sufficiently full material is consulted, it will be seen that there are really no characters which remain after the characters common to Mactras and Mulinias are excluded, upon which even a subfamily can be based. The distinctive characters of the genera of the Mactrida merge so gradually from one form into another that we are forced to the opinion that Gray and Desmoulins were right, and that the group can only be ranked as a genus, next to Mulinia, in the Mactroid series.

In the endeavor to come to a well-founded conclusion in regard to the affinities of Gnathodon, a careful examination was made of the soft parts of $G$. cuneatus from Mobile and Texas; Mactra (Spisula) similis, Say, Florida; M. (S.) polynyma Stm., Alaska; M. (Mulinia) lateralis Say, Massachusetts; Cyrena carolinensis and Cyrena floridana Conrad, from Florida. I received half a dozen Gnathodons from Mobile Bay alive, by mail, through the kind intervention of Mr. G. D. Harris ; and others, in alcohol, from Port Lavaca, Texas, from Mr. J. D. Mitchell. Several errors were found in Rang's account of the macroscopic anatomy, leading to the suspicion that he dealt with specimens which had already been removed from the shell when he received them. The following notes were made from the specimens:

The foot of Gnathodon cuneatus is like that of Mactra, but shorter and more compressed. There is no external indication of a byssal gland. The retractor muscle of the foot on each side is attached to the underside of the cardinal border above and near the adductor.

The siphons of Gnatminlon are short, but united to the ends, as in Mactra. The incurrent siphon is papillose at its orifice, the excurrent siphon smooth-edged, or very finely papiliose, differing in different specimens. The external surface of the siphons is of a dark olive color, nearly black where most intense, with a lighter line conforming to the intersection of the vertical plane between the valves with the siphonal commissure. The mantle:margin is wide and smooth, the distal edge thin, blending with the papery epidermis, the inner edge thick, smooth, and somewhat elevated. The anterior commissure is in front of the adductor, thence backward the lobes are separated three-fourths of the way to the siphons, much as in Mactra. A short distance within the margin, beginning in the posterior half of the shell and extending backwards to a point under the shade of the valve of the incurrent siphon is an elevated raphe of tissue which divides the incurrent channel. A similar arrangement is found in Mactra, but not in Cyrena. This ridge is probably the seat of sensory tissue analogous to the osphradium of Gastropods.

'T'ue palps are triangular, slender, rather long, the lower ones extending to the posterior fourth of the foot on each side, continuous below the mouth, where they are soldered to the visceral mass, and joined 
above with the inner anterior edges of the somewhat shorter upper pair. The inner surfaces of both are striated, the outer surfaces smooth. Rang indicates the mouth below the lower palps, which is obviously erroneous.

The gills are of moderate size, two on each side, the inner pair larger, and hung by their upper edges from the visceral mass. The attachment of the outer pair is about a millimeter higher, separated from the suture of the inner gills by a fine very tender membrane; the line of attachment divides the outer gill at its upper third, the upper portion is more or less fixed upon the mantle by slender adhesions toward its middle third, and bent downward, but is more free before and behind. This reflected portion of the outer gill is what is often referred to as the "appendix." Both gills are joined by a delicate membrane behind the retractor pedis (where the width of the two gills is approximately equal) to each other, to the pair of the opposite side and to the siphonal septum, forming a complete partition between the anal and peripedal chambers. This is also found in the various forms of Mactra examined and in Cyrena floridana, though in the latter the attachments are extremely delicate. Below the septum in Gnathodon a thin arched membrane forms an imperfect valve at the base of the incurrent siphon, as in Mactra, but in Cyrena this was hardly perceptible. The whole surface of the gills is finely striated, of a dull cream color, vertically barred with about twenty dark brown transverse lines. In all the other species examined the gills were colorless. In Rang's figure the anal and peripedal chambers are wrongly represented as communicating behind the gills, which error was doubtless due to rupture of the membranes. .18

So far as the soft parts are concerned, it will be seen from the preceding notes that Gnathodon, Mactra, and Cyrena agree essentially in the general structure and attachments of the gills, in having a separate anal chamber, in the general form of the foot (shortest in Cyrena and longest in Mactra), in the separation of the mantle lobes (somewhat greater in Cyrena), and in the absence of a byssus.

Gnathodon agrees with Mactra in having the siphons united to their ends and the incurrent one furnished with an imperfect basal valve aud with an elevated raphe behind it. It agrees with the Mactrida in having an internal cartilage and with Mulinia in having both the (ordinarily external) ligament and cartilage internal and contained in the same socket. In all these features Mactra and Gnathodon differ from Cyrena and its allies, all of which have only an external ligament set in a groove and separated by an elongated fulcrum, or nympha, from the cardinal border.

In considering the evidence of the harder parts all the species of Gnathodon must be examined, the typical species being more extreme in its characters than any of the others. It is also necessary to examine very young specimens, which are extremely difficult to get hold of, notwithstanding the abundance of the species on the Gulf coast. 
My much regretted friend, the late Dr. Paul Fischer, in his Manual has compared Rangia to a Cyrena with an internal cartilage, and has regarded the cardinal teeth of the former as alternating, or Heterodont, and those of Mactra as of the type which has been called Desmodont by Neumayr. For these reasons he placed his family Rangiida immediately after Cyrenide in the Manual. If he had been able to study the series which has been available for me I can not doubt he would have changed this opinion. A study of the young shows that the hinge of Gnathodon in its early stages is as typically Desmodont as that of Mactra and that the truncation of the $\Lambda$-shaped teeth is a dynamic feature due to the exigencies of growth, which may be observed in Mulinia as well as Gnathodon. As a matter of fact neither Mactra nor Gnathodon has genuine Desmodont dentition. The hinges of both are really Heterodont.

In the young Gnathodon cuneatus $10 \mathrm{~mm}$. long, the hinge possesses the following armature:

Left valve: Anterior lateral tooth slender, slightly arched, crenulate above, behind without the characteristic hook from which Gray derived his name for the genus; cardinal tooth thick, $\Lambda$-shaped, with a pronounced depression on each side of it; anterior border of the cartilagepit with a small accessory lamella; the upper part of the anterior border showing a small blunt projection corresponding to the hiatus between the cartilage and the ligament above; this is probably a relic of the shelly bridge which roofed the pit before the ligament descended into it; pit deep, its ventral border projecting as in Mactra; the insertion scars of ligament above and cartilage below entirely separate, with a small shelly ridge rising between them; posterior lateral long, thiu, slender, arched, crenulate above.

Right valve: Furrow for the anterior lateral tooth narrow, crenulate on both sides, the lamina below it not much thickened; cardinal teeth two simple lamelle closely approximated (but not joined) at their upper ends, with a $\Lambda$-shaped pit below them, into which is received the cardinal tooth of the opposite valve; (this arrangement is exactly paralleled in Mulinia lateralis); posterior groove for the lateral of the left valve narrow, crenulate on both sides; the lower lamina slightly more prominent than the upper one; other features as in the left valve.

At this stage the pallial sinus is proportionally larger and rounded anteriorly as in Mactra, in short all the distinctive characters of the young shell, in which it differs from the adult, are Mactroid.

Looked at from the standpoint of dynamic evolution, the hinge of this group and the other Mactrida in its development offers much that is of interest. The various stages of immersion of the ligament in the different genera and subgenera illustrate well the manner in which it has been ingulfed. So too the changes between the juvenile hinge and that of the full-grown adult when regarded from a dynamic standpoint are more easy of explanation than from any other point of view. 
Gnathodon seems to be indifferent as to the salinity of the water in which it lives, as it is found both in the sea outside of the lagoons and in the brackish water of the lagoons, while the living specimeus received by me from Mobile Bay seemed to maintain perfect health for some four or five days in perfectly pure fresh water. But there is no doubt that it is, by preference, like the oyster; an inhabitant of waters the salinity of which has been diluted by their proximity to the mouths of rivers or creeks. In common with the majority of pelecypods inhabiting fresh or brackish water, it has acquired the habit of secreting a very heavy shell which is almost always eroded a good deal by the free carbon dioxide of such locations.

The peculiar hooked or jaw-shaped anterior lateral, which, in connection with the longer posterior lateral, is the most marked characteristic of the genus, results from the inequality of the two laminæ between which it is inserted in the opposite valve. In Mulinia (from which Gnathodon seems to be an off-shoot) the laminæ and teeth are alike short and somewhat removed from the vicinity of the cardinal teeth. In Gnathodon, however, the laminæ are prolonged until they are very close to the cartilage pit behind and to the cardinal teeth in front. The lower anterior lamina, for some unknown reason, did not attain the same length and there is a gap between the cardinal tooth and the end of the low er lamina. In Gnathodon, as in other pelecypods, the surface of the mantle is produced in such a way as to secrete and deposit the shelly matter demanded by the growth of the hinge. The ventral exposures of the hinge and its laminæ are those upon which deposition is most profuse and direct, consequently the gap referred to was rapidly filled by deposition from below on the ventral face of the projecting part of the upper lamina. The process may be seen in its successive stages in any good series of Gnathodon cuneatus. Once the "hook" is formed, it molds to a greater or less extent the form of the tooth impinging upon it, and is preserved, among other reasons, because the triangular buttress which it finally becomes is the most efficient obstacle which the hinge possesses to the rotation of the valves on the cartilage as a center. The tendency to this rotation, potentially very injurious, has been promoted by the degeneration and immersion of the ligament. Consequently it is not at all improbable that the "hook" is a character which would be enlarged and preserved by natural selection. The oldest species (clathrodon) has it least developed, the most abundant recent species (cuneatus) most so. It is distinctly present in all the known species, but not always conspicuous. In the adult the efficient action of the hinge is promoted by distinct, usually transverse, crenulations on opposed surfaces. Where the surfaces are flat the crenulations are usually parallel grooves, but on rounded surfaces, such as the point of the lower anterior lamina in the right valve, they may be wavy, granular, or irregular. The end they serve is that of decreasing the tendency to any wobbling of the hinge, and these crenulæ are 
merely the result of the same processes which developed the original hinge teeth in the prionodont saction of the Paleopelecypoda. Where the motion is purely to and fro, giving rectilinear friction of the opposed surfaces, the rugæ must be parallel and regular, corresponding to the direction of the movement. Where the motion may be slightly irregular, corresponding irregularities will appear in the rugosities. The tendency of the development of rugæ is to confine and limit the range of motion in the interest of the safety of the mollusk, a tendency which culminates in the interlocking rigid hinge of Plicatula and Spondylus. Contrary to the supposition of Neumayr, I believe there is no fundamental distinction between the groups possessing Desmodont and Het. erodont hinge teeth, but that both are developed according to the particular circumstances of the case; the immersion of the ligament and development of a cartilage may occur in some genera of any natural group.

Typical species.

GNATHODON CUNEATUS, Gray.

Plate VII, figs. 1 and 10.

Gnathodon cuneatus, Gray, Sowerby, Genera of Sh., Part xxxvi, figs. 1-3,1831.GraY, P. Z.S. 1836, p. 104; Loudon's Mag. N. H., n. s., 1, p. 376, fig. 34, 1838.Conrad, Medial Tertiary, No.1, p. 23,1838.-Anton, Verz.Conch., p. 10, 1839.Sowerby, Man. Conch., 1st ed., fig. 83, 1839; 2nd ed., p. 154. fig. 83, 1842.Swainson, Malac., p. 370, 1840.-Reeve, Conch. Syst., I, p. 62, pl. 43, 1841.Conrad, 2nd Bull. Nat. Inst., pp. 190, 192, 1842.-De KA Y, Zool. N. York, Moll., p. 233, pl. 25, fig. 267, 1843.-Hanley, Descr. Cat. Rec. Sh., p. 35, pl. 10, fig. 22, 1843.-Gray, Gen. Moll. P. Z. S. 1847, p. 186.-PhilipPi, Handb. Conch., p. 317, 1853.-Holmes, Post Pl. Fos. S. Car., p. 41, Pl. vir, fig. 10, 1860.Dall, Bull. 37, U. S. Nat. Mus., p. 62, 1889.

Rangia cyrenoides, Desmoulins, Actes Soc. Lin. de Bordeaux, v., p. 57, figs. 1-3, Feb. 15, 1832.-Conral, Am. Marine Conch. pp. 56, 57, Pl. XiII, 1832.-H. \&

- A. Adams. Gen. Rec. Moll., II, p. 380, Pl. 100, figs. 4, 4a, 1856.-Conrad, Proc. Acad. N. Sci. Phila. 1860, p. 232, 1861 ; Medial Tert. U. S., Index, p. 88, 1861.Prime, Proc. Bost. Soc. N. H., vir, p. 347, 1861.-Conrad, Am. Journ. Conch., III, app., p. 30, Cat. Mactrida, 1868.-Fischer, Man. de Conchyl.,p. 1096, Pl. Xxi,fig. 2, 1887.

Gnathodon Grayi, Tuomey \& Holmes, Pleioc. Fos. S. Car.. p. 99, pl. 23, fig. 11, 1857; not of Conrad; Ibid., Post Pl. Fos., p. 41, 1860.

Gnathodon minor, Holmes, Post Pl. Fos. S. Car., p. 41, 1860; in synonymy.

Clathradon cuneata, (Gray Ms.) Conrad, Am. Marine Conch., p. 57, 1833; Am. Journ. Sei., 1st ser., xxiII, p. 340,1833.

Pliocene of the Carolinas and of Florida (Caloosahatchee beds). Pleistocene of Cornfield Harbor, Chesapeake Bay, and Wailes' Bluff. Potomac River; of South Carolina; of Florida; of the whole north coast of the Gulf of Mexico and on the north coast of South America (?), Lea; Pleistocene(?) of Matamoras, Mexico, Dugés; Living in Mobile Bay, Alabama, and westward on the north shore of the Gulf to Vera Cruz, Mexico, in shallow water, either brackish or perfectly salt. I have re-

Proc, N, M. 94-7 
ceived from Mr. J. D. Mitchell, of Texas, a living specimen upon which an oyster, at least two years old, and several specimens of Mytilus hamatus were firmly attached.

Details in regard to this species will be found under the discussion of the genus. I am informed that on the Texas coast it has been extensively preserved for food in cans under the name of "Little Neck Clams," and has met with some favor, gastronomically.

The dimensions of an adult specimen are as follows: Length 75, height 60 , diameter $50 \mathrm{~mm}$; but the proportions vary somewhat with the amount of rostration of the individual.

The epidermis of $G$. cuneatus is normally of an ashy gray color, sometimes with a tinge of greenish or brownish, and of a papery consistency. When worn it has a more brownish tint, and some specimens display streaks of a light ferruginous brown when the epidermis is thick and worn. There is sometimes shown a smoother and more translucent area of epidermis in the region where the lunule and escutcheon of bivalves usually occur, though these areas are not set off by any groove; but they are chiefly visible in adolescent specimens and often absent entirely. Toward the posterior end of the shell the epidermis is often raised in fine wrinkles, and it is usually more or less eroded on the beaks. The sculpture of the exterior of the valves is chiefly incremental and irregular, but many specimens show traces of radiating raised threads, especially in the rostral region. A wide obscure depression extending from the beaks to the margin and, with the valves closed, circumscribing a cordate area, is visible on the anterior end of many specimens. It corresponds nearly to the lower part of the anterior adductor scars within the valves. No umbonal sculpture like that of many unios can be observed on the uneroded beaks. They are always smooth, as in Mactra.

In common with most brackish water shells this species has a considerable range of variability in form. In this case it chiefly arises from a difference in the height of the umbones, and especially from the shape of the posterior extreme of the shell, which normally is somewhat produced and evenly rounded at the margin, but in other cases is somewhat rostrated, with the basal margin somewhat concavely flexuous. This is carried to an extreme in a variety which may be called

GNATHODON CUNEATUS var. NASUTUS, Dali.

Plate VII, fig. 8 .

In salt water at Port Lavaca, Texas, Mitchell.

Length 35, height 27 , diameter $24 \mathrm{~mm}$., in the typical specimen. This form was found by Mr. Mitchell, with others of the typical character, in pure salt water on the Texas coast. The specimen is small compared with the adult of the type form, but seems mature and is quite thick. It has nearly the form of $G$. flexuosus, but can at once be 
discriminated from the latter by the presence of a deep though small pallial sinus and a long, arched, posterior lateral tooth.

GNATHODON CLATHRODON, Con rad (emended).

Plate VII, fig. 9.

Mactra clathrodonta, ConRad, Am. Journ. Sei., 1st ser., Xxiri, p. 340, 1832.

Gnathodon grayi, Conra D, Medial Tert., p. 23, pl. 13, fig. 1, 1838; Ibid., second ed. by Dall, 1893.-Emmons, Geol. Rep. N. Car., p. 298, fig. 226a, 1858.

Gnathodon minor, Conrad, Medial Tert., p. 69, pl. 39, fig. 6, May, 1840 (Testa junior). Am. Journ. Sci., 1st ser., XLI, p. 347, pl. 2, fig. 14, Oct., 1841. Not of Whitfield.

Rangia minor, Conrad, Proc. Acad. Nat. Sci. Phila., xiI, p. 232, 1861.

Rangia clathrodonta, Conrad, op. cit., XiI, p. 232, 1861.-Prime, Proc. Bost. Soc. N. Hist., viI, p. 347, 1861.

Rangia (Perissodon) clathrodonta, Conrad, Proc. Acad. Nat. Sci. for 1862, p. 573, 1863.-Merk, Smithsonian Misc. Coll. 183, Checkl. Inv. Fos. Mioc. N. Am., p. 11, 1864.

Rangia (Perissodon) minor, Conrad, Proc. Acad. Nat. Sci., Phila. for 1862, p. 573, 1863.-MEEK, Checklist, p. 11, 1864.

Chesapeake Miocene of James and York rivers, Virginia and North Carolina, Conrad, Ruffin, and Yarrow; Pliocene of the Croatan beds in North Carolina, Johnson.

The dimensions of an adult specimen are: Length, 70; height, 54.5; diameter, $40 \mathrm{~mm}$.

This is the oldest species of the genus, and appears in the Chesapeake Miocene of Virginia, but seems to be very limited in its distribution. I have seen no specimens from south of North Carolina. It may be discriminated from $G$. cuneatus by its thinner and more compressed shell, its slender and straighter lateral teeth, its more shallow and open cartilage pit, its less prominent and more adjacent beaks. The pallial sinus is small but angular. The lateral teeth are crenulate, especially above; the posterior end of the shell, though not rostrate, is rather pointed.

A subgenus Perissodon proposed for this species by Conrad, but never defined, seems to have been based on the specific differences above referred to. There are certainly no features of more than specific value separating this form from $G$. cuneatus. I am quite confident that Conrad's G. minor, described from the same beds as G. clathrodon, is merely a young stage of the latter. Conrad's figure agrees with such young shells very well, and his description affords no differential characters. 
GNATHODON LECONTEI, Con rad.

Plate VII, fig. 4.

Gnathodon Lecontei, Conrad, Journ. Acad. Nat. Sci. Phila., 2d Ser., II, p. 273, pl. 24, figs. 1-3, Jan., 1853; Proc. Acad. Nat. Sci., viI, p. 31-Gould, in Pac. R. R. Rep., v.; appendix, p. 230, 1855.

Rangia Lecontei, ConraD., Proc. Acad. Nat. Sci. Phila. for 1860 , p. 232, 1861.Мекк, S. I. Checkl. foss. N. Am., Miocene, p. 11, 1864.

Fossil in the upper Tertiary (Pliocene?) rocks on Carisco Creek, Colorado desert, Arizona, Dr. Leconte. Type in the National Museum, Reg. No. 6833.

Length, $22 \mathrm{~mm}$.; height, 20 ; diameter, 16.

This species, which is said to occur in great abundance at the locality mentioned, most nearly resembles $G$. cuneatus but is a more trigonal shell than specimens of cuneatus of the same length, has a smaller pallial sinus, and is a considerably smaller and less heavy species. There are also differences in the arrangement of teeth on the hinge line. It differs from G. trigonus Petit in having long lateral teeth and in being proportionately more elevated. The beaks are high and more closely adjacent than in G. cuneatus. Carpenter (Rep. Brit. Assoc. Moll. W. C. N. Am., 1863, p. 592) correctly distinguishes this species from $G$. mendicus or trigonus, and recognized its greater resemblance to the G. cuneatus. No specimens seem to have been collected by any one since Dr. Leconte, who described them as found in a layer of rock two feet thick in the bank of the creek, where they occurred in the greatest profusion. The small pallial sinus in this species is a step in the direction of Rangianella.

\section{Section MIORANGIA, Dall. \\ GNATHODON JOHNSONI, Dall.}

Plate VII, fig. 7.

Gnathodon Johnsoni, Dall, Science, Vol. xx, No. 502, p. 165, September 16, 1892 (name only); Trans. Wagner Inst. III, p. 337, pl, 22, fig. 18, December, 1892.

Venus mobiliana, Johnson, Science, Vol. xx, No. 501, p. 151, September 9, 1892 (name only).

Fossil in the Miocene of the Pascagoula clays at Shell Bluff, Pascagoula River, Greene County, Miss.; also at a depth of 700 feet in the artesian well at Biloxi, Miss., and of 735 feet in the artesian well at Mobile, Ala.; L. C. Johnson.

Shell small, rather compressed, ovate-triangular to submytiliform in outline, rather thin for the genus, externally smooth or marked only with lines of growth when perfectly normal, but frequently concentrically tluctuate owing to irregularities of growth; beaks prominent, compressed, anterior, close to the hinge line; margin of the shell entire, with no circumscribed lunule or escutcheon; interior smooth, muscular impressions small, distinct; pallial line with a shallow incurvation behind, hinge very asymmetrical, the anterior lateral tooth in the left 
valve, short, $\Lambda$-shaped, received in the right valve into a corresponding sulcus, below which a triangular pustule represents the anterior lateral of that valve; cardinal teeth of the left valve diverging, lamellar, the anterior lamella situated above the anterior lateral tooth, fitting above a triangular cardinal tooth grooved or partly split at the apex, in the right valve; posterior lateral tooth in the left valve long, arched, finely crenate above, received in the right valve between two slender laminæ, of which the lower one is most prominent; pit for the ligament and cartilage narrow, oblique, roofed over by a very thin shelly layer generally worn off in rubbed specimens. Length of shell 17.5; height 1.15; double diameter of valve, $10 \mathrm{~mm}$. Fragments indicate that the species reaches a length of at least $25 \mathrm{~mm}$.

This species differs from the young of $G$. cuneatus in the fact that the $\Lambda$-shaped cardinal tooth is in the right valve when the valves are closed, while in G. cuneatus it is in the left valve, as well as in clathrodon, Lecontei, mendicus and flexuosus. In G.Johnsoni the anterior lateral tooth is shorter, relatively, than in any other species, and the shell is more drawn out behind the beaks.

The geological age of this species is somewhat in doubt. It is associated with Hydrobia mobiliana Dall, and with a large oyster and Mulinia lateralis var. corbuloides Reeve. The latter is a living species and is not otherwise known below the newer zones of the Chesapeake Miocene. The Pascagoula clays were referred to the Grand Gulf beds by Hilgard, and overlie them. There is no doubt that the typical Grand Gulf beds are included between the Hawthorne beds, at the base of the older Miocene, and certain beds of the Chipola series; at present it seems improbable that the Pascagoula clays can be correlated with any thing older than the Chesapeake. I am disposed to consider them as corresponding to the aluminous clay above the Chesapeake clay-marl in the Alum Bluff series.

Subgenus Rangianella, Con rad.

Rangianella, Conrad, Am. Journ. Conch., III, Suppl. p. 30, 1867.

Rangia, Carpenter, Mazatlan Shells, p. 53, 1857.

Lateral teeth short, subequal, about equidistant from the beaks, feebly striated or smooth; shell of moderate size, subelongate or rostrate, long: than high; pallial sinus inconspicuous or obsolete.

Type: Gnathodon trigonus, Petit $=G$. mendicus, Gould.

The hook of the anterior lateral tooth is almost obsolete in this species, especially in the young, and it was chiefly upon this character that Conrad separated it, leaving $G$. flexuosus with the typical species; but the sum of all the characters, if taken into account, would modify this view. Carpenter saw the difference ten years earlier, and would have utilized the name Rangia for the short-toothed species; but this proceeding would be contrary to the accepted rules of nomenclature, since Rangia was based solely upon the same species as Gnathodon, and must stand or fall with the priority of application to that special type. 
GNATHODON (RANGIANELLA) MENDICUS, G o u 1 d.

Plate VII, fig. 2.

Mactra mendica, Gould., Proe. Bost. Soc. Naţ. Hist., IV, p. 88, Nov., 1851; Journ. B. S. N. H., vi, p. 393, Pl. xv, fig. 4, Oct., 1853.

Gnathodon mendicus, Carpenter, P. Z. S. 1856, p. 200; Mazatlan Sh., p. 549, 1857; Rep. Br. Assoc. 1863, pp. 535, 543, 592.

Gnathodon trigonum, PeTiT, Journ. de Conchyl. iv, pp. 84, 166, Pl. vi, figs. 13-15, 1853.-Carpenter, P. Z. S. 1856, p. 200 ; Rep. Br. Assoc. 1857, p. 227 ; Rep. Br. Assoc. 1863, pp. 535, 543, 576, 592, 633.

Gnathodon trigona, CarPenter, Mazatlan Sh., p. 52, 1857.

Gnathodon truncatum, PetrT, Journ. de Conchyl. IV, p. ii, of expl. pl., 1853.

Gnathodon Lecontei, Conrad. Proc. Acad. Nat. Sci., VII, p. 31, 1854; not of Conrad, Journ. Acad. 1853.

Rangia trigona, Adams, Gen. Rec. Moll. II, p. 380, 1858.

Rangia mendica. Prime, Proc. B. S. N. H. vir, p. 347, 1861.

Rangianella trigona, Conrad. Am. Jour. Conch., III, suppl., p. 30, 1868.

Mazatlan, Mexico, Lieut. Green, Rolland de Roquan, Reigen, etc.; living in brackish water.

Ihave examined authentic specimens of both G.mendicus and G.trigonus and there seems to be no doubt of their identity.

The epidermis of this species is of a straw color, varying to greenish yellow, darker on the posterior slope, where it often becomes fibrous, and having a paler lozenge-shaped area over the hinge, which, however, is not circumscribed by any groove. Internally the shell is polished outside of the area inclosed by the pallial line. The latter is feebly waved, but hardly indented. The lateral teeth are nearly equal, feebly granulose, the anterior with the "hook" almost obsolete. Although the shell usually has a smooth internal margin it is sometimes radiately striated, especially above the hinge, and the lines of growth are often beaded here and there with short radiating threads much more regular and distinct than those sometimes notable on G. cuneatus. A faint wrinkled sculpture is constantly present on the posterior slope and seems characteristic of the species. The umbones are quite smooth. The specimens I have seen average about $25 \mathrm{~mm}$. (1 inch) in length, $18 \mathrm{~mm}$. in height, and $12.5 \mathrm{~mm}$. in diameter.

\section{GNATHODON (RANGIANELLA) FLEXUOSUS, C on rad .}

Plate VII, figs. 3,6 .

Gnathodon flexuosus, Conrad, Am. .Journ. Sci., 1st ser., xxxviri, p. 92, fig. 1839; Proc. Acad. Nat. Sci. Phila., viI, p. 31, 1855.

Gnathodon rostratum, Petit, Journ. de Conchyl. IV, pp. 84, 164, Pl. v., figs. 1-3, 1853.

Rangia Alexuosa, Conrad, Proc. Acad. Nat. Sei. Phila. for 1860, p. 232; Am. Journ. Conch., III, supplem., p. 30, 1868.

Rangia rostrata, Prime, Proc. Bost. Soc. N. Hist., viI, p 348, 1861.-Adams, Gen. Rec. Moll., II, p. 380, 1858.-Conrad, Am. Journ. Conch., III, suppl., p. $30,1868$.

Living on the coast of the Gulf of Mexico from northern Florida to Vera Cruz, Mexico, in suitable places. Apparently a denizen of pure salt water. 
Length, 43; height, 30 ; diameter, $26 \mathrm{~mm}$. in the adult.

This is apparently a rare species. I have never seen a perfectly fresh specimen. It can be distinguished from any other Atlantic species by its short, subequal, lateral teeth, rostrate shape, and obsolete pallial sinus. The erenulations of the teeth are very feeble and, in worn specimens, sometimes invisible; but this is a character which varies much in individuals, as can be observed in any good series of G.cuneatus. The shell is much heavier than G. mendicus, and has the lateral teeth more unequal, the anterior lateral being strongly hooked. The pallial line has no reëntrani angle, but a recess is formed by the base of the adductor scar and the vertical extension of the pallial impression. The epidermis is straw yellow. I have observed no beading along the lines of growth, and no sculpture, on the posterior slope, except incremental lines, on any of the specimens I have examined. The shell varies a good deal in height relative to its length, and the posterior end may be flexed upward or downward or produced horizontally. It is perceptibly rostrate. I have called attention to the fact that $G$. cuneatus has a rostrate variety, of which the outline simulates that of $G$. Alexuosus, and must now add a peculiar variety of $F_{\text {. }}$. Alexuosus which tends in the opposite direction.

GNATHODON FLEXUOSUS var. PETITIANUS, D a 11 .

Plate VII, fig. 5.

In this variety the shell has a height of 30 and a length of $36.5 \mathrm{~mm}$. compared with a height of 29 and a length of $43 \mathrm{~mm}$. for the typical flexuosus; the posterior slope is convex and the rostrum short, rounded, and bent downward, the pallial line has a faint sinuation, and the "hook" on the anterior lateral is obsolete. The diameter of the shell would be about $21 \mathrm{~mm}$. The valve is lighter than any specimens of G. flexuosus which have come to my notice and considerably more swollen. It is possible that it may represent a distinct species, but this can not be determined without a good series of fresh specimens. A single somewhat worn left valve was obtained by the Mexican geographical commission at Vera Cruz, and is now in the National Museum (No. 57668a).

I have referred it to G. flexuosus on account of the short lateral teeth and feeble pallial sinus; if additional material should prove it to be distinct, the varietal name now given may be taken as specific. No indication of external sculpture except incremental lines is visible; the epidermis is absent from the specimen.

G. Alexuosus possesses more constantly than any other species a character occasionally found in each of them, namely, the presence at the anterior border of the cartilage pit of a thin accessory lamella between the pit and the deltoid eardinal tooth of the left valve. This lamella, when perfect, looks like an additional cardinal tooth, and is always best developed in the left valve, but it is usually more or less absorbed or even absent. It is common to all the Mactrida. The mar- 
gin of the valves, especially near the hinge, sometimes shows faint radiating striation, as already noticed in $G$. mendicus.

\section{Spurious or Doubtful Species.}

\section{MULINIA GUADELUPENSIS, Recluz.}

Mactra guadelupensis, Recluz, Journ. de Conchyl., III, p. 249, pl. 10, figs. 4, 4', 1852 ; Journ. de Conchyl., iv, p. 414, 1853.-BEaU, Cat. Sh. Guad., p. 26, 1858.Krebs, W. I. Marine Sh., p. 105, 1864.

Gnathodon guadalupensis, ReEve, Conch. Icon., XIx, No. 2, 1873.

Mactra donaciformis, Krebs, W. I. Mar. Shells, p. 105, 1864; not of Gray or Reeve. Gnathodon Cantrainei (Recluz ms.), Reeve., Conch. Icon., Xix, Gnathodon, fig. 3 , Oet., 1873.--Gundlach, Ann. Soc. Esp. de Hist. Nat., xiI, pr. 280, 322, 1883.

Beach at Aguadilla, Porto Rico, dead shells cast up on the shores of the creek, Gundlach; Nevis, Sowerby; Guadelupe, Recluz, Beau; Guaivea on the coast of Venezuela, Blume in Swift Coll.

Gray described a shell in 1837 under the name of donaciformis, but his description was inadequate. It was later figured by Sowerby in the zoology of the voyage of the Blossom, Capt. Beechey, and ou this figure the name must rest, as there is no other means of identifying the shell. It represents a species found on the west coast of middle America from Panama to the Colorado River. It is quite a variable shell but normal specimens agree well with Sowerby's figure. It was stated by Gray to come from the "South Seas" (then a term including most of the Pacific); Sowerby gave the locality as "Nevis," an island in the West Indies where Beechey did not touch; later Reeve figured a shell, probably young, said to be from New Zealand, under Gray's name. The reference to "Nevis" led Krebs and others to identify a rather similar but smaller species named guadelupensis by Recluz with the donaciformis of Sowerby and Gray. Recluz' species was subsequently figured by Sowerby (1873) in his continuation of Reeve's Iconica as a Gnathodon, a not unnatural mistake, since these Mulinias and Rangianella can barely be separated generically. At the same time another Mulinia, probably a mere variety of guadelupensis, is figured by Sowerby under the (ms.?) name of Cantrainei Recluz, and also referred to Gnathodon. From an examination of authentic specimens there seems to be no question of the identity of $G$. Cantrainei with $G$. guadelupensis, while it is absolutely certain that both belong to the genus Mulinia of Gray.

This, however, is not the final disposition of the matter. The small Mulinia, named lateralis by Say, is well known, chiefly from northern specimens. It extends from Massachusetts Bay to the Antilles. The northern specimens are rather rude, but a series showing the geographical range also shows that, as we follow the species south, it becomes more delicate, lighter, and develops several varieties, one of which was named Mactra rostrata by Philippi (not of Spengler) and Mactra corbuloides, by Deshayes. This rostrate form is connected with the type by insensible gradations. The species nnder favorable circum- 
stances attains the length of an inch and is quite variable in form, as are all these small Mulinias. It is my opinion that a complete geographical series will show that $M$. guadelupensis is merely a wellgrown local race of the M. lateralis. Both have a preference for brackish water.

\section{GNATHODON? VALDENSIS, D u n k er.}

Gnathodon valdensis, DUNK ER, Monog. Norddeutsch. Wealdenbild., p. 57, taf. XIII, Figs. 5 a-e, 1846.-SANDberger, Land und Siisswasser conchyl. der Vorwelt, p. 54, Pl. II, Figs. 10, 10a, 1870.

Wälderthon des Gravinghagener stolleus bei Bielefeld, Germany; Wealden formation of North Germany.

This species has the aspect of a Cyrena. The interior and hinge are unknown. It was referred to Gnathodon by Dunker because the specimens give no evidence of an external ligament. It is highly improbable that the shell will finally prove to belong to Gnathodon, both on account of its age and its locality, but it will certainly be a matter of interest to determine its proper place and it is to be hoped that this will soon be accomplished.

\section{SPISULA? QUADRICENTENNIALIS, H arris .}

Gnathodon, new sp., Harris, Fourth Ann. Rep. Texas Geol. Survey, Table of species Galveston well, 1893.

Gnathodon quadricentennialis, Harris, Fifth Ann. Rep. Texas Geol. Survey. [In press].

From the upper Miocene, 2100 to 2250 feet, in the Galveston artesian well, Galveston, Texas; State Geological Survey.

After a careful examination of specimens of this species kindly furnished by Prof. Harris, I am inclined to refer this to Spisula, notwithstanding the inequality of the lateral teeth. The ligament appears to have been partly external, which would remove the species from Gnathodon, unless this feature is due to wear, which seems unlikely. The shell is nearly smooth externally, rather elongated, evenly rounded at each end, quite inequilateral, the longer posterior part having long curved laterals, transversely striated. The hinge seems otherwise like that of Spisula; the pallial sinus is well marked, the beaks adjacent, low, and inconspicuous, $1.5 \mathrm{~mm}$. from the anterior end. Lon. 8.5, alt. 5.0, diam. $4.0 \mathrm{~mm}$.

\section{MULINIA MINOR, Whitfield?}

Rangia? (Perissodon) minor, Whitfield, Moll. and Crust. of the Miocene form of N. J., p. 84, pl. 15, figs. 4-6 [in press]; not of Conrad.

Miocene marl of Shiloh, N. J., Burns.

This species doubtfully referred to Conrad's $R$. minor $[=G$. clathrodon, jr.], and well figured by Prof. Whitfield, is a young Mulinia allied to $M$. lateralis, but too young to identify. The type is in the collection of the National Museum. Only one specimen was obtained by Mr. Burns. 
SPISULA? PARVA, Petit.

Gnathodon parvum, PetrT, Journ. de Conchyl., iv, p. 358, pl. 13, figs. 9-10, 1853.ReEve, Conch. Icon., Xix, Gnathodon, fig. 6, 1873.

Rangia parva, Adams, Gen. Rec. Moll., II, p. 380, 1858.-Conrad, Proc. Acad. Nat. Sci. Phila. for 1860, p. 232; Am. Journ. Conch., III, Suppl., p. 30, 1868.

Mactra rostrata, ReEve, Conch. Icon., viII, Mon. Mactra, Pl. XIx, fig. 104, 1854; not of Philippi, Zeitschr. Mal., 1848, p. 152, nor of Spengler, 1802.

Brisbane River, Moreton Bay, Australia, Petit.

Specimens of Petit's shell in the National Museum received from $H$. Cuming were named by the latter Mactra rostrata, Spengler. Spengler cites for a figure of his species the Conchylien Cabinet, vol.12, tab. 242, fig. 4197, but there is no such plate or figure in the volume referred to, though he may have had proofs of a plate which never was published. His species is quite distinct, but Reeve has figured our shell, as identified by Cuming, under Spengler's name. The shell is a Spisula, the ligament being externally visible, though partly inserted in the cartilage pit. The laterals are very sharply striated. In the specimen received from Cuming the lateral teeth proper are in the left valve.

\section{ISOCARDIA? TENUIDENS, Wh it field.}

Gnathodon? tenuidens, Whitfield, Lam. Raritan Clays, p. 27, pl. 11, figs. 7-10, 1885.

This species is only known as an internal east from the Cretaceous beds known as the Plastic Clays of New Jersey. It is a thin-shelled salt water bivalve, having much the appearance of an Isocardia. It was but doubtfully referred to the genus Gnathodon by Whitfield, and I believe it should be referred to the Isocardiida. It has nothing but the prominent and distant beaks to connect it with Gnathodon.

\section{EXPLANATION OF PLATE VII.}

Fig. 1. Gnathodon cuneatus, Gray, exterior of adult specimen $60 \mathrm{~mm}$. long. Mus. Reg. No. 60793, p. 93.

Fig. 2. Gnathodon mendicus, Gould, interior of specimen $23.5 \mathrm{~mm}$. long. Mus. Reg. No. 103899 , p. 98.

Fig. 3. Gnathodon flexuosus, Conrad, exterior of an adult specimen $43 \mathrm{~mm}$. long. Mus. Reg. No. 6134, p. 98.

Fig. 4. Gnathodon Lecontei, Conrad, one of the typical specimens, the hinge somewhat weatherworn, length $22 \mathrm{~mm}$. Mus. Reg. No. 6833, p. 96.

Fig. 5. Gnathodon flexuosus var. Petitianus, DALL, from the typical specimen $36.5 \mathrm{~mm}$. long. Mus. Reg. No. 57668a, p. 99.

Fig. 6. Gnathodon flexuosus, ConRAD, interior, the shell a little worn, the same specimen is figured at fig. $3 ; \mathrm{p} 98$.

Fig. 7. Gnathodon Johnsoni. Dall, type specimen $17.5 \mathrm{~mm}$. long. Mus. Reg. No. 107033 , p. 96.

Fig. 8. Gnathodon cuneatus var. nasutus, DALL, interior of type specimen $34 \mathrm{~mm}$. long, Mus. Reg. No. 106988, p. 94.

Fig. 9. Gnathodon clathrodon, CONRAD (em.), interior of specimen $40 \mathrm{~mm}$. long, from the Croatan beds, Pliocene of North Carolina. Mus. Reg. No. 112296, p. 95.

Fig 10 Gnathodon cuneatus, GraY, interior of valve $60 \mathrm{~mm}$. long. Mus. Reg. No. 60793 , p. 93. 


\section{$2 \mathrm{BHL}$ Biodiversity Heritage Library}

Dall, William Healey. 1894. "Monograph of the genus Gnathodon, Gray (Rangia, Desmoulins)." Proceedings of the United States National Museum 17(988), 89-106. https://doi.org/10.5479/si.00963801.17-988.89.

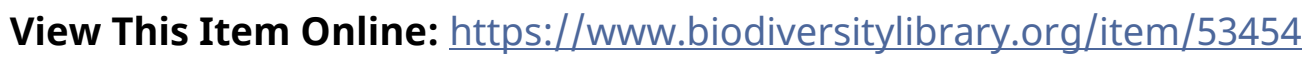

DOI: https://doi.org/10.5479/si.00963801.17-988.89

Permalink: https://www.biodiversitylibrary.org/partpdf/52126

\section{Holding Institution}

Smithsonian Libraries

\section{Sponsored by}

Smithsonian

\section{Copyright \& Reuse}

Copyright Status: Public domain. The BHL considers that this work is no longer under copyright protection.

This document was created from content at the Biodiversity Heritage Library, the world's largest open access digital library for biodiversity literature and archives. Visit BHL at https://www.biodiversitylibrary.org. 